\title{
Side Streets
}

\section{Eli Goldblatt}

Reflection: Poems explore places not accessible to academic or even personal prose. Words in lines can sound interior depths at the same time as they can reflect, record or conjure external scenes. In the ancient Chinese Taoist/Buddhist poetic tradition known as "Rivers and Mountains," the poet or painter's long sorrow or momentary joy is always embedded in the larger landscape of cliffs and waterfalls, distances and heights that dwarf human action. The pandemic forced us all into greater solitude but also generated an acute awareness of the needs and struggles that neighbors and strangers were living through. In 2020 my wife, artist Wendy Osterweil, and I walked nearly every day in the Wissahickon Creek Park, a deeply wooded area in Philadelphia with 56 miles of trails. We also delivered for our food coop now and then to seniors who lived in food deserts and couldn't leave their apartments. Poems allow for inside and outside occurrences to exist without direct judgment or analysis. "Side Streets" comes from a series I wrote during this period called Walks \& Dreams.

Snow on side streets narrows

heart's arteries to alleys.

Quarantined in two rooms

the knitter barely able to fit

her walker thru a channel

walled by magazines $\&$ news

moves from sitting room to

bed, kidney bean cans \&

Ritz cracker packs

stacked on kitchen counter. Set

the box anywhere, she says,

do I know you? Roads 
lead to store but she's

not taking that trip anymore-

payment late, landlord

might lock her out, drop

her things on pavement

tree roots jacked up.

Outside I watch robins

feast on berries they find

in vines wrapping dead

oaks along old railroad

tracks. Shoe shop shuttered

but next door they still

sell coffee \& damp doughnuts.

I listen to sparrows fuss \& a

woodpecker searches for grubs.

\section{Author Bio}

Eli Goldblatt's poems have appeared in literary journals since 1972. His fourth poetry collection is For Instance (Chax P 2019). His 2020 book on literacy, co-written with David Jolliffe, is Literacy as Conversation: Learning Networks in Philadelphia and Arkansas (U of Pittsburgh P). He is Professor Emeritus of English at Temple University. 